Marquette University

e-Publications@Marquette

Theology Faculty Research and Publications

Theology, Department of

$1-1-2012$

\title{
The Sacerdotal Traditions of 2 Enoch and the Date of the Text
}

Andrei Orlov

Marquette University, andrei.orlov@marquette.edu

Published version. "The Sacerdotal Traditions of 2 Enoch and the Date of the Text," in New

Perspectives on 2 Enoch: No Longer Slavonic Only. Eds. Andrei Orlov, Gabriele Boccaccini, and Jason

Zurawski. Leiden: Brill, 2012: 103-116. DOI. (C) 2012 Brill. Used with permission. 


\title{
THE SACERDOTAL TRADITIONS OF 2 ENOCH AND THE DATE OF THE TEXT
}

\author{
Andrei A. Orlov
}

\section{Introduction}

In previous studies experts have repeatedly raised concerns about the date of the apocalypse, noting that the text does not seem to supply definitive chronological boundaries. Indeed, while for the last hundred years 2 Enoch has been consistently included in various collections of early pseudepigraphical texts, scholarly studies show some ambiguity and caution in their treatment of the apocalypse as a sample of early Jewish thought, given the uncertainty of the text's date. Alongside this ambiguity and caution, one often finds references to Francis Andersen's remark that "in every respect 2 Enoch remains an enigma. So long as the date and location remain unknown, no use can be made of it for historical purposes."1 However, the uncritical use of Andersen's reference to 2 Enoch as an enigma "in every respect" simplifies 2 Enoch scholarship, trivializing the value of the long and complex history of efforts to clarify the date of the text. The current study will deal with the history of research on the sacerdotal traditions in the apocalypse which constitute an important cluster of motifs scholars often use to demystify the text's date.

\section{Early Debates about the Date}

Already in 1896, in his introduction to the English translation of 2 Enoch, Robert Henry Charles assigned "with reasonable certainty" the composition of the text to the period between $1-50$ C.E., ${ }^{2}$ before the destruction of

\footnotetext{
${ }^{1}$ F. I. Andersen, "2 (Slavonic Apocalypse of) Enoch," in The Old Testament Pseudepigrapha, ed. J. H. Charlesworth, 2 vols. (New York: Doubleday, 1983, 1985), 1:97.

2 In his introduction to the Forbes' translation of 2 Enoch in APOT, Charles broadened the range of the dating of the apocalypse, postulating that " 2 Enoch in its present form
} 
the temple; this view, however, did not remain unchallenged. ${ }^{3}$ In 1918 the British astronomer A. S. D. Maunder launched an attack against the early dating of the pseudepigraphon, arguing that 2 Enoch does not represent an early Jewish text written in the first century C.E., but instead is "a specimen of Bogomil propaganda," composed in the Slavonic language in "the 'Middle Bulgarian' period-i.e., between the 12th and 15th centuries." ${ }^{4}$ In the attempt to justify her claim, Maunder appealed to the theological content of the book, specifically to its alleged Bogomil features, such as the dualism of good and evil powers. She found that such dualistic ideas were consistent with the sectarian teaching that "God had two sons, Satanail and Michael." Maunder's study was not limited solely to the analysis of the theological features of the text but also included a summary of the astronomical and calendrical observations which attempted to prove a late date for the text. Her argument against the early dating of the pseudepigraphon was later supported by J. K. Fotheringham, who offered a less radical hypothesis that the date of 2 Enoch must be no earlier than the middle of the seventh century C.E. ${ }^{6}$

Scholars have noted that Maunder's argumentation tends to underestimate the theological and literary complexities of 2 Enoch. The remark was made that, after reading Maunder's article, one can be "astonished at the weakness of this argument and at the irrelevant matters adduced in support of it."7 Charles responded to the criticism of Maunder and Fotheringham in his article published in 1921 in the Journal of Theological Studies, in which he pointed out, among other things, that "the Slavonic Enoch, which ascribes the entire creation to

was written probably between 30 B.C. and A.D. 70. It was written after 30 B.C., for it makes use of Sirach, 1 Enoch, and the Book of Wisdom ..., and before A.D. 70; for the Temple is still standing." R. H. Charles and N. Forbes, "The Book of the Secrets of Enoch," in The Apocrypha and Pseudepigrapha of the Old Testament, ed. R. H. Charles, 2 vols. (Oxford: Clarendon, 1913), 2:429. This opinion about the early date of 2 Enoch was also supported by Charles' contemporaries, the Russian philologist Matvej Sokolov and German theologian Nathaniel Bonwetsch.

3 R. H. Charles and W. R. Morfill, The Book of the Secrets of Enoch (Oxford: Clarendon Press, 1896), xxvi.

4 A. S. D. Maunder, "The Date and Place of Writing of the Slavonic Book of Enoch," The Observatory 41 (1918): 309-316 (esp. 316).

5 Maunder, "The Date and Place of Writing of the Slavonic Book of Enoch," 315.

${ }^{6}$ J. K. Fotheringham, "The Date and the Place of Writing of the Slavonic Enoch," JTS 20 (1919): 252.

7 A. Rubinstein, "Observations on the Slavonic Book of Enoch," JJS 15 (1962): 1-21 (3). 
God and quotes the Law as divine, could not have emanated from the Bogomils."8

Another attempt to question the scholarly consensus about the early date of 2 Enoch was made by Josef Milik in his introduction to the edition of the Qumran fragments of the Enochic books published in 1976. ${ }^{9}$ In the introductory section devoted to 2 Enoch, Milik proposed that the apocalypse was composed between the ninth and tenth centuries C.E. by a Byzantine Christian monk who knew the "Enochic Pentateuch" "in the form with which we are familiar through the Ethiopic version."10 In order to support his hypothesis of a late date Milik draws attention to several lexical features of the text. One of them is the Slavonic word змоурениемь (zmureniem' $)^{11}$ found in 2 Enoch 22:11 which Milik has traced to the Greek

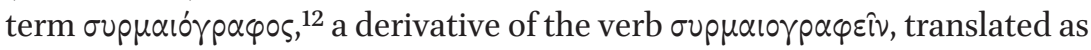
"to write in minuscule, hence quickly."13 He argues that this verb appears to be a neologism which is not attested in any Greek text before the beginning of the ninth century. In addition in his analysis of the lexical features of the apocalypse, Milik directed attention to the angelic names of Arioch and Marioch found in 2 Enoch 33, arguing that they represent the equivalents of the Harut and Marut of the Muslim legends attested in the second surah of the Qur'an. ${ }^{14}$

John Collins, among others, has offered criticism of Milik's lexical arguments, noting that even if the Slavonic text uses the Greek word

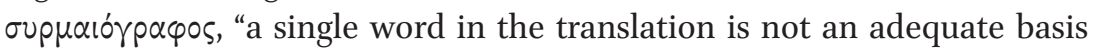

8 R. H. Charles, "The Date and Place of Writings of the Slavonic Enoch," JTS 22 (1921): 162-3. See also K. Lake, "The Date of the Slavonic Enoch," HTR 16 (1923): 397-398.

9 J. T. Milik, The Books of Enoch: Aramaic Fragments of Qumran Cave 4 (Oxford: Clarendon Press, 1976).

10 Milik, The Books of Enoch, 109.

11 M. I. Sokolov, "Материалы и заметки по старинной славянской литературе. Выпуск третий. VII. Славянская Книга Еноха Праведного. Тексты, латинский перевод и исследование. Посмертный труд автора приготовил к изданию М. Сперанский," Чтения в Обществе Истории и Древностей Российских 4 (1910): 1-167 (23, n. 13).

12 Milik's hypothesis is implausible. Most scholars trace the word змоурениемь (zтигеniem') to the Slavonic змоурьна (zmur'na) which corresponds to $\sigma \mu v \dot{p} v \alpha$, myrrha. J. Kurz, ed., Slovnik Jazyka Staroslovenskeho (Lexicon Linguae Palaeoslovenicae), 4 vols. (Prague: Akademia, 1966), 1:677-8. Andersen's translation renders the relevant part of 2 Enoch 22:11 as follows: "And Vereveil hurried and brought me the books mottled with myrrh." Andersen, "2 Enoch," 1:141.

13 Milik, The Books of Enoch, 111.

14 Milik, The Books of Enoch, 110. 
for dating the whole work." 15 He has also pointed out that "the alleged correspondence of the angels Arioch and Marioch to Harut and Marut of Muslim legend is indecisive since the origin of these figures has not been established."16

Milik's arguments were not confined only to the lexical features of the apocalypse. He also argued that the priestly succession from Methuselah to Noah's nephew Melchizedek described in the third part of 2 Enoch reflects "the transmission of monastic vocations from uncle to nephew, the very widespread custom in the Greek Church during the Byzantine and medieval periods." 17 This feature in his opinion also points to the late Byzantine date of the pseudepigraphon. It should be noted that Milik's insistence on the Byzantine Christian provenance of the apocalypse was partially inspired by the earlier research of the French Slavist André Vaillant who argued for the Christian authorship of the text. ${ }^{18}$ Vaillant's position too generated substantial critical response since the vast majority of readers of 2 Enoch had been arguing for the Jewish provenance of the original core of the text. ${ }^{19}$

\section{The Sacerdotal Traditions and the Date of the Text}

Our previous analysis shows that none of the arguments against the early dating of the pseudepigraphon stands up to criticism and that no convincing alternative to the early date has so far been offered. ${ }^{20}$

15 J. J. Collins, "The Genre Apocalypse in Hellenistic Judaism," in Apocalypticism in the Mediterranean World and the Near East, ed. D. Hellholm (Tübingen: Mohr Siebeck, 1983), 533, n. 7 .

16 Collins, "The Genre Apocalypse in Hellenistic Judaism," 533, n. 7.

17 Milik, The Books of Enoch, 114.

18 A. Vaillant, Le Livre des secrets d'Hénoch: Texte slave et traduction française, Textes publiés par l'Institut d'études slaves 4 (Paris: L'Institut d'études slaves, 1976 [1952]).

19 Some of the supporters of the idea of the Jewish authorship of the text include the following scholars: Amusin, Andersen, Bonwetsch, Böttrich, Bousset, Charles, Charlesworth, Collins, De Conick, Delcor, Denis, Eissfeldt, Ginzberg, Gieschen, Greenfield, Gruenwald, Fletcher-Louis, Fossum, Harnak, Himmelfarb, Kahana, Kamlah, Mach, Meshcherskij, Odeberg, Pines, Philonenko, Riessler, Sacchi, Segal, Sokolov, de Santos Otero, Schmidt, Scholem, Schürer, Stichel, Stone, and Székeley.

20 The early date of the pseudepigraphon was supported by, among others, the following investigations: Charles and Morfill, The Book of the Secrets of Enoch; Sokolov, "Материалы и заметки по старинной славянской литературе. Выпуск третий. VII. Славянская Книга Еноха Праведного. Тексты, латинский перевод и исследование. Посмертный труд автора приготовил к изданию М. Сперанский;" G. N. Bonwetsch, 
Still, one should recognize that, while the adoption of an early date for the text itself does not face great challenges, placing the text within the precise boundaries of Second Temple Judaism is a much more difficult task.

In proceeding to this task one must first understand what features of the text point to the early date of the text in the chronological framework of Second Temple Judaism. It is noteworthy that the vast majority of scholarly efforts have been in this respect directed towards finding possible hints that might somehow indicate that the temple was still standing when the original text was composed..$^{21}$

Thus, scholars have previously noted that the text does not seem to hint that the catastrophe of the destruction of the temple has already occurred at the time of its composition. Critical readers of the pseudepigraphon would have some difficulties finding any explicit expression of feelings of sadness or mourning about the loss of the sanctuary.

The affirmations of the value of the animal sacrificial practices and Enoch's halakhic instructions also appear to be fashioned not in the "preservationist," mishnaic-like mode of expression, but rather as if they reflected sacrificial practices that still existed when the author was writing his book. ${ }^{22}$

Das slavische Henochbuch, AGWG.PH Neue Folge Bd.1 Nr.3 (Berlin: Weidmannsche Buchhandlung, 1896); N. Schmidt, "The Two Recensions of Slavonic Enoch," JAOS 41 (1921): 307-312; G. Scholem, Ursprung und Anfänge der Kabbala (Berlin: de Gruyter, 1962), 62-64; M. Philonenko, "La cosmogonie du 'Livre des secrets d'Hénoch,' " in Religions en Egypte: Hellénistique et romaine (Paris: Presses Universitaires de France, 1969), 109-116; S. Pines, "Eschatology and the Concept of Time in the Slavonic Book of Enoch," in Types of Redemption, ed. R. J. Zwi Werblowsky and C. Jouco Bleeker, SHR 18 (Leiden: Brill, 1970), 72-87; J. C. Greenfield, "Prolegomenon," in H. Odeberg, 3 Enoch or the Hebrew Book of Enoch (New York: KTAV, 1973), XVIII-XX; U. Fischer, Eschatologie und Jenseitserwartung im hellenistischen Diasporajudentum, BZNW 44 (Berlin: de Gruyter, 1978), 38-41; J. H. Charlesworth, "The SNTS Pseudepigrapha Seminars at Tübingen and Paris on the Books of Enoch (Seminar Report)," NTS 25 (1979): 315-23; Collins, "The Genre Apocalypse in Hellenistic Judaism," 533; Andersen, "2 (Slavonic Apocalypse of) Enoch;" M. E. Stone, Jewish Writings of the Second Temple Period: Apocrypha, Pseudepigrapha, Qumran Sectarian Writings, Philo, Josephus, CRINT 2.2 (Assen: Van Gorcum, 1984), 406; A. de Santos Otero, "Libro de los secretos de Henoc (Henoc eslavo)," in Apocrifos del AT, ed. A. Diez Macho (Madrid: Ediciones Christiandad, 1984), 4:147-202; C. Böttrich, Das slavische Henochbuch (Gütersloh: Gütersloher Verlaghaus, 1995), 812-13; P. Sacchi, Jewish Apocalyptic and its History, JSPSup 20 (Sheffield: Sheffield Academic Press, 1996).

${ }^{21}$ Fischer, Eschatologie und Jenseitserwartung im hellenistischen Diasporajudentum, 40-41; Böttrich, Das slavische Henochbuch, 812-13.

22 Enoch 59. 
There is also an intensive and consistent effort on the part of the author to legitimize the central place of worship, which through the reference to the place $A k h u z a n^{23}$ (a cryptic name for the temple mountain in Jerusalem), is transparently connected in 2 Enoch with the Jerusalem Temple. ${ }^{24}$

Scholars have also previously noted that there are some indications in the text of the ongoing practice of pilgrimage to the central place of worship; these indications could be expected in a text written in the Alexandrian Diaspora. ${ }^{25}$ Thus, in his instructions to the children, Enoch repeatedly encourages them to bring the gifts before the face of God for the remission of sins, a practice which appears to recall well-known sacrificial customs widespread in the Second Temple period. ${ }^{26}$

Moreover, 2 Enoch also contains a direct command to visit the temple three times a day, advice that would be difficult to fulfill if the sanctuary has already been destroyed. ${ }^{27}$

One can see that the crucial arguments for the early dating of the text are all linked to the themes of the sanctuary and its ongoing practices and customs. These discussions are not new; already Charles employed the references to the temple practices found in 2 Enoch as main proofs for his hypothesis of the early date of the apocalypse. Since Charles' pioneering research these arguments have been routinely reiterated by scholars.

In recent scholarship one can see continuation of this line of inquiry involving close analysis of the sacerdotal traditions in attempt to clarify the possible date of the text.

A few years ago Christfried Böttrich broadened the familiar lines of debate through a nuanced investigation of several sacerdotal traditions in the third part of 2 Enoch. In a study published in 1995 and an article appearing subsequently in the Journal for the Study of Judaism in 2001, Böttrich draws attention to a tradition in Chapter 69 which deals with

23 Slav. Ахоузань.

24 In Ezek 48:20-21 the Hebrew word אחזה), "special property of God," is applied to Jerusalem and the Temple. Milik, The Books of Enoch, 114.

25 Böttrich, Das slavische Henochbuch, 813 .

262 Enoch 61:1-5; 62:1-2.

272 Enoch 51:4: "In the morning of the day and in the middle of the day and in the evening of the day it is good to go to the Lord's temple on account of the glory of your creator.” Andersen, “2 Enoch,” 178. 
the joyful festival marking Methuselah's priestly appointment and his animal sacrifices. ${ }^{28}$ Böttrich proposes that this cult-establishing event falls on the 17th of Tammuz, which is identified in 2 Enoch as the day of the summer solstice. Böttrich links this solar event with the imagery in 2 Enoch 69, where Methuselah's face becomes radiant in front of the altar "like the sun at midday rising up." He then reminds us that, since the second century C.E., the 17 th of Tammuz was observed as a day of mourning and fasting because it was regarded as the day when Titus conquered Jerusalem. ${ }^{29}$ Böttrich suggests that, lacking any signs of sadness or mourning, the description of the joyful festival in 2 Enoch 69 suggests that the account and, consequently, the whole book were written before the fall of Jerusalem and the destruction of the temple in 70 C.E. ${ }^{30}$

Böttrich's study of the sacerdotal developments in the third part of the pseudepigraphon is important for understanding the conceptual mold of these cultic traditions that appear to reflect second temple settings.

It is possible that this portentous cluster of sacerdotal traditions introduced in 2 Enoch's final part, which is permeated with the imagery of the sacrificial rites and priestly successions, contains a set of decisive clues for unlocking the mystery of this enigmatic text's date.

Another important chronological marker appears to be hinted at in the strong presence of the early priestly Noachic motifs in this final portion of the apocalypse - the cluster of unique traditions that shows remarkable similarities to the Second Temple Jewish developments found in the early Enochic booklets and the Qumran materials.

\section{The Priestly Noachic Traditions}

It is well known that the birth of Noah occupies an important place in early Enochic and Noachic materials which portray the hero of the flood

\footnotetext{
28 Böttrich, Das slavische Henochbuch, 813. See also C. Böttrich, "The Melchizedek Story of 2 (Slavonic) Enoch: A Reaction to A. Orlov," JSJ 32.4 (2001): 451.

29 y. Ta ${ }^{\mathrm{c}}$ an. $68 \mathrm{c}$ and $b$. Ta ${ }^{\mathrm{c}}$ an. $26 \mathrm{~b}$.

30 Böttrich, Das slavische Henochbuch, 813 .
} 
as a wonder child. ${ }^{31} 1$ Enoch $106,{ }^{32}$ the Genesis Apocryphon, ${ }^{33}$ and possibly ${ }_{1}$ Q19 ${ }^{34}$ depict him with a glorious face and eyes "like the rays of the sun." 1 Enoch 106:2 relates that when the new-born Noah opened his eyes, the whole house lit up. The child then opened his mouth and blessed the Lord

31 On Noachic traditions, see M. Bernstein, "Noah and the Flood at Qumran," in The Provo International Conference on the Dead Sea Scrolls: Technological Innovations, New Texts, and Reformulated Issues, ed. D. W. Parry and E. Ulrich, STDJ 30 (Leiden: Brill, 1999), 199-231; D. Dimant, "Noah in Early Jewish Literature," in Biblical Figures Outside the Bible, ed. M. E. Stone and T. A. Bergren (Harrisburg, PA: Trinity Press International, 1998), 123-50; F. García Martínez, Qumran and Apocalyptic, STDJ 9 (Leiden: Brill, 1992), 24-44; García Martínez, "Interpretation of the Flood in the Dead Sea Scrolls," in Interpretations of the Flood, ed. F. García Martínez and G. P. Luttikhuizen, TBN 1 (Leiden: Brill, 1998), 86-108; C. H. T. Fletcher-Louis, All the Glory of Adam: Liturgical Anthropology in the Dead Sea Scrolls (STDJ, 42; Leiden: Brill, 2002), 33ff.; R. V. Huggins, "Noah and the Giants: A Response to John C. Reeves," JBL 114 (1995): 103-110; H. Kvanvig, Roots of Apocalyptic: The Mesopotamian Background of the Enoch Figure and the Son of Man, WMANT 61 (Neukirchen-Vluyn: Neukirchener Verlag, 1988), 242-54; J. Lewis, A Study of the Interpretation of Noah and the Flood in Jewish and Christian Literature (Leiden: Brill, 1968); G. W. E. Nickelsburg, "Patriarchs Who Worry About Their Wives: A Haggadic Tendency in the Genesis Apocryphon," in Pseudepigraphic Perspectives: The Apocrypha and the Pseudepigrapha in Light of the Dead Sea Scrolls, ed. E. Chazon and M. E. Stone, STDJ 31 (Leiden: Brill, 1999), 137-158; J. Reeves, "Utnapishtim in the Book of Giants?" JBL 12 (1993): 110-15; J. M. Scott, "Geographic Aspects of Noachic Materials in the Scrolls of Qumran," in The Scrolls and the Scriptures: Qumran Fifty Years After, ed. S. E. Porter and C. E. Evans, JSPSup 26 (Sheffield: Sheffield Academic Press, 1997), 368-81; R. C. Steiner, "The Heading of the Book of the Words of Noah on a Fragment of the Genesis Apocryphon: New Light on a 'Lost' Work," DSD 2 (1995): 66-71; M. Stone, "The Axis of History at Qumran," in Pseudepigraphic Perspectives: The Apocrypha and the Pseudepigrapha in Light of the Dead Sea Scrolls, ed. Chazon and Stone, 13349; M. Stone, "Noah, Books of," in Encyclopaedia Judaica (Jerusalem: Keter, 1971), 12:1198; J. VanderKam, "The Righteousness of Noah," in Ideal Figures in Ancient Judaism: Profiles and Paradigms, ed. J. J. Collins and G. W. E. Nickelsburg, SBLSCS 12 (Chico: Scholars Press, 1980), 13-32; J. VanderKam, "The Birth of Noah," in Intertestamental Essays in Honor ofJózef Tadeusz Milik, ed. Z. J. Kapera, Qumranica Mogilanensia 6 (Krakow: The Enigma Press, 1992), 213-31; C. Werman, "Qumran and the Book of Noah," in Pseudepigraphic Perspectives: The Apocrypha and the Pseudepigrapha in Light of the Dead Sea Scrolls, ed. Chazon and Stone, 171-81.

321 Enoch 106:5: "... his eyes (are) like the rays of the sun, and his face glorious...." M. Knibb, The Ethiopic Book of Enoch: A New Edition in the Light of the Aramaic Dead Sea Fragments, 2 vols. (Oxford: Clarendon, 1978), 2:244-5.

33 1QapGen 5:12-13: “... his face has been lifted to me and his eyes shine like [the] s[un...] (of) this boy is flame and he...." F. García Martínez and E. J. C. Tigchelaar, eds., The Dead Sea Scrolls Study Edition, 2 vols. (Leiden: Brill, 1997), 1:31.

34 A similar tradition is reflected in 1Q19. 1Q19 3: “... were aston[ished...] [... (not like the children of men) the fir]st-born is born, but the glorious ones [...] [...] his father, and when Lamech saw [...] [...] the chambers of the house like the beams of the sun [...] to frighten the [...]." 1Q19 13: "[...] because the glory of your face [...] for the glory of God in $[\ldots][\ldots$ he will] be exalted in the splendor of the glory and the beauty $[. .$.$] he will be$ honored in the midst of [...]." García Martínez and Tigchelaar, eds., The Dead Sea Scrolls Study Edition, 1:27. 
of heaven. Scholars have previously noted ${ }^{35}$ that the scene of the glorious visage of the young hero of the flood delivering blessings upon his rising up from the hands of the midwife has a sacerdotal significance and parallels the glorious appearance and actions of the high priest. ${ }^{36}$ The scene manifests the portentous beginning of the priestly-Noah tradition. ${ }^{37}$

In 2 Enoch, this prominent part of Noah's biography finds a new niche where the peculiar details of Noah's story are transferred to another character, the miraculously born priest Melchizedek. ${ }^{38}$

35 Fletcher-Louis, All the Glory of Adam, $33 \mathrm{ff}$.

36 Crispin Fletcher-Louis notes parallels between this scene and the description of the ideal high priest from Sirach 50 . He argues that "in Sirach 50 the liturgical procession through Simon's various ministrations climaxes with Aaron's blessings of the people (50:20, cf. Numbers 6) and a call for all the readers of Sirach's work 'to bless the God of all who everywhere works greater wonders, who fosters our growth from birth and deals with us according to his mercy' (50:22). So, too, in 1 Enoch 106:3 the infant Noah rises from the hands of the midwife and, already able to speak as an adult, 'he opened his mouth and blessed the Lord.' " Fletcher-Louis, All the Glory of Adam, 47.

37 Fletcher-Louis argues that "the staging for [Noah's] birth and the behavior of the child have strongly priestly resonances." Fletcher-Louis, All the Glory of Adam, 46.

38 The cluster of the Noachic motifs takes place in the last chapters of 2 Enoch (chaps. 68-72). In this section of the pseudepigraphon we learn that, immediately after Enoch's instructions to his sons during his short visit to the earth and his ascension to the highest heaven, the firstborn son of Enoch, Methuselah, and his brothers, the sons of Enoch, constructed an altar at Akhuzan, the place where Enoch had been taken up. In 2 Enoch 69 the Lord appeared to Methuselah in a night vision and appointed him as priest before the people. Verses $11-16$ of this chapter describe the first animal sacrifice of Methuselah on the altar. The text gives an elaborate description of the sacrificial ritual during which Methuselah slaughters with a knife, "in the required manner," sheep and oxen placed at the head of the altar. All these sheep and oxen are tied according to the sectarian instructions given by Enoch earlier in the book. Chapter 70 of 2 Enoch recounts the last days of Methuselah on earth before his death. The Lord appeared to Methuselah in a night vision and commanded him to pass his priesthood duties on to the second son of Lamech, the previously unknown Nir. The text does not explain why the Lord wanted to pass the priesthood to Nir instead of Noah (Lamech's firstborn son), even though Noah is also mentioned in the dream. Further, the book tells that Methuselah invested Nir with the vestments of priesthood before the face of all the people and "made him stand at the head of the altar." The account of the sacerdotal practices of Enoch's relatives then continues with the Melchizedek story. The content of the story is connected with Nir's family. Sothonim, Nir's wife, gave birth to a child "in her old age," right "on the day of her death." She conceived the child, "being sterile" and "without having slept with her husband." The book narrated that Nir the priest had not slept with her from the day that the Lord had appointed him in front of the face of the people. Therefore, Sothonim hid herself during all the days of her pregnancy. Finally, when she was at the day of birth, Nir remembered his wife and called her to himself in the temple. She came to him and he saw that she was pregnant. Nir, filled with shame, wanted to cast her from him, but she died at his feet. Melchizedek was born from Sothonim's corpse. When Nir and Noah came in to bury Sothonim, they saw the child sitting beside the corpse with "his clothing on him." According to the story, they were terrified because the child was fully developed physically. The child spoke with his lips and he blessed the Lord. According to the story, the newborn child was marked with the 
Scholars have previously pointed out that Melchizedek's birth in 2 Enoch recalls some parallels with the birth of Noah in 1 Enoch and the Genesis Apocryphon. ${ }^{39}$ The details of Noah's natal account correspond at several points with the Melchizedek story:

1. Both Noah and Melchizedek belonged to the circle of Enoch's family.

2. Both characters are attested as survivors of the flood.

3. Both characters have an important mission in the postdiluvian era.

4. Both characters are depicted as glorious wonder children.

5. Immediately after their birth, both characters spoke to the Lord.

1 Enoch 106:3 relates that “... when he (Noah) arose from the hands of the midwife, he opened his mouth and spoke to the Lord with righteousness." A similar motif is attested in 2 Enoch 71:19 where Melchizedek "... spoke with his lips, and he blessed the Lord."40

6 . Both characters were suspected of divine/angelic lineage.

M. Delcor affirms that Lamech's phrase in the beginning of the Genesis Apocryphon, "Behold, then I thought in my heart that the conception was the work of the Watchers and the pregnancy of the Holy Ones..." can be compared with the words of Noah in 2 Enoch uttered at the time of examining Melchizedek: "This is of the Lord, my brother." ${ }^{11}$

7. The fathers of both infants were suspicious of the conception of their sons and the faithfulness of their wives. ${ }^{42}$ Thus, in the Genesis

sacerdotal sign, the glorious "badge of priesthood" on his chest. Nir and Noah dressed the child in the garments of priesthood and they fed him the holy bread. They decided to hide him, fearing that the people would have him put to death. Finally, the Lord commanded his archangel Gabriel to take the child and place him in "the paradise Eden" so that he might become the high priest after the flood. The final passages of the story describe the ascent of Melchizedek on the wings of Gabriel to the paradise Eden.

39 See M. Delcor, "Melchizedek from Genesis to the Qumran Texts and the Epistle to the Hebrews," JSJ 2 (1971): 129; Delcor, "La naissance merveilleuse de Melchisédeq d'après l'Hénoch slave," Kecharitomene. Mélanges René Laurentin, ed. C. Augustin, et al. (Paris: Desclée, 1990), 217-229; G. W. E. Nickelsburg, Jewish Literature between the Bible and the Mishnah (Philadelphia: Fortress, 1981), 185; A. de Santos Otero, "Libro de los secretos de Henoc (Henoc eslavo)," Apocrifos del Antiguo Testamento, ed. A. Díes Macho, 4 vols. (Madrid: Ediciones Jesusiandad, 1984), 4:199; R. Stichel, Die Namen Noes, seines Bruders und seiner Frau. Ein Beitrag zum Nachleben jüdischer Überlieferungen in der außerkanonischen und gnostischen Literatur und in Denkmälern der Kunst, AAWG.PH 3. Folge 112 (Göttingen: Vandenhoeck \& Ruprecht, 1979), 42-54.

40 Andersen, "2 Enoch," 207.

41 Delcor, "Melchizedek from Genesis to the Qumran Texts and the Epistle to the Hebrews," 129.

42 George Nickelsburg observes that the miraculous circumstances attending Melchizedek's conception and birth are reminiscent of the Noah story in 1 Enoch, although the suspicion of Nir is more closely paralleled in the version of the Noah story in the Genesis Apocryphon. Nickelsburg, Jewish Literature between the Bible and the Mishnah, 188. 
Apocryphon, Lamech is worried and frightened about the birth of Noah, his son. Lamech suspects that his wife Bathenosh was unfaithful to him and that "the conception was (the work) of the Watchers and the pregnancy of the Holy Ones, and it belonged to the Nephil[in]."43 The motif of Lamech's suspicion about the unfaithfulness of Bathenosh found in the Genesis Apocryphon seems to correspond to Nir's worry about the unfaithfulness of Sothonim. 2 Enoch relates that when “... Nir saw her [Sothonim]... he became very ashamed about her. And he said to her, 'what is this that you have done, $\mathrm{O}$ wife? And why have you disgraced me in the front of the face of all people? And now, depart from me, go where you conceived the disgrace of your womb. " 44

8. Mothers of both heroes were ashamed and tried to defend themselves against the accusation of their husbands. Thus, in the Genesis Apocryphon, the wife of Lamech responds to the angry questions of her husband by reminding him of their intimacies: "Oh my brother and lord! remember my sexual pleasure... [...] in the heat of intercourse, and the gasping of my breath in my breast." 45 She swears that the seed was indeed of Lamech: "I swear to you by the Great Holy One, by the King of the hea[vens...] ... [...] that this seed comes from you, $[. .$.$] and not from any$ foreigner nor from any of the watchers or sons of heav[en]." ${ }^{46}$ In 2 Enoch Sothonim does not explain the circumstances of the conception. She answers Nir: "O my lord! Behold, it is the time of my old age, and there was not in me any (ardor of) youth and I do not know how the indecency of my womb has been conceived." 4

9. Fathers of both sacerdotal infants were eventually comforted by the special revelation about the prominent future role of their sons in the postdiluvian era. ${ }^{48}$

One cannot fail to notice host of interesting overlaps between the birth of Noah in the Noachic materials and the birth of Melchizedek in 2 Enoch.

43 García Martínez and Tigchelaar, eds., The Dead Sea Scrolls Study Edition, 1:29.

44 Andersen, “2 Enoch," 205.

45 García Martínez and Tigchelaar, eds., The Dead Sea Scrolls Study Edition, 1:29.

46 García Martínez and Tigchelaar, eds., The Dead Sea Scrolls Study Edition, 1:29-31.

47 Andersen, “2 Enoch,” 205.

481 Enoch 106:16-18- "And this son who has been born unto you shall be left upon the earth, and his three sons shall be saved when they who are upon the earth are dead." 2 Enoch 71:29-30- "And this child will not perish along with those who are perishing in this generation, as I have revealed it, so that Melchizedek will be... the head of the priests of the future." It is noteworthy that this information is given in both cases in the context of the revelation about the destruction of the earth by the flood. Andersen, "2 Enoch," 208. 
The analysis of the Noachic background of the Melchizedek natal account in 2 Enoch and its sacerdotal flavor leads us to the important question about the role of these Noachic developments in discerning of the early date of the apocalypse. It is possible that the presence of these early priestly Noachic themes reflected in 2 Enoch can represent a testimony which hints to the fact that the text was composed when the second temple was still standing.

The central evidence here is the priestly features of the miraculous birth of the hero. The main concern of the story of the wondrous birth was sacerdotal; the story is permeated with imagery portraying the newborn as the high priest par excellence. It also has been shown that the mold of the Noachic priestly tradition reflected in 2 Enoch belongs to the same set of conceptual developments reflected in such Second Temple Enochic and Noachic materials as 1 Enoch 106, the Genesis Apocryphon, and 1Q19. The priestly features of 2 Enoch's account of the wondrous birth might thus point to the fact that this narrative and, as a consequence, the whole macroform to which it belongs was written in the second temple period. It should be emphasized again that the distinct chronological marker here is not the story of the wonder child itself, which was often imitated in later Jewish materials, but the priestly features of the story that are missing in these later improvisations.

The analysis of the later pseudepigraphic and rabbinic imitations of the account of Noah's birth shows that the priestly dimension of the story never transcended the boundaries of the Enochic-Noachic lore, nor did it cross the chronological boundary of 70 C.E. since it remained relevant only within the sacerdotal context of the second temple Enochic-Noachic materials. Although some later Jewish authors were familiar with the account of Noah's birth, this story never again became the subject of priestly polemics once the dust of the destroyed temple settled.

Several examples can illustrate this situation. In search of the later variants of the story of the wonder child Fletcher-Louis draws attention to the account of Cain's birth in the primary Adam books. ${ }^{49}$ Thus, the Latin Life of Adam and Eve 21:3 relates that Eve "brought forth a son who shone brilliantly (lucidus). At once the infant stood up and ran out and brought some grass with his own hands and gave it to his mother. His name was called Cain." ${ }^{50}$ Fletcher-Louis points out that this narrative of the wonder

49 Fletcher-Louis, All the Glory of Adam, 51-52.

50 G. A. Anderson and M. E. Stone, A Synopsis of the Books of Adam and Eve. Second Revised Edition, SBL.EJL 17 (Atlanta: Scholars, 1999), 24-24E. See also Armenian and Georgian versions of LAE: "Then, when she bore the child, the color of his body was like the 
child recalls the story of Noah. Yet he notes that "all the features which in the birth of Noah signal the child's priestly identity — solar imagery, birth in a house and child's blessing of God are markedly absent in the Adamic story." 51 Such absence of the significant features can be an indication that the final form of the text was composed outside the chronological boundaries of Second Temple Judaism and therefore, unlike 2 Enoch, displays no interest in the sacerdotal dimension of the story. Although the authors of the LLAE might have been familiar with the narrative of Noah's birth, the priestly concerns associated with the story were no longer relevant for them.

The same situation of the absence of the sacerdotal concern is observable also in the rabbinic stories of Moses' birth reflected in $b$. Sotah 12a, ${ }^{52}$ Exod. R. 1:20, ${ }^{53}$ Deut. R. 11:10, ${ }^{54}$ PRE 48, ${ }^{55}$ and the Zohar II.11b, ${ }^{56}$ whose authors were possibly cognizant of the Noachic natal account.

Reflecting on this evidence Fletcher-Louis notices that, although the authors of the rabbinic accounts of Moses' birth appear to be familiar with Noah's narrative, these materials do not show any interest in the

color of stars. At the hour when the child fell into the hands of the midwife, he leaped up and, with his hands, plucked up the grass of the earth..." (ALAE). "Eve arose as the angel had instructed her: she gave birth to an infant and his color was like that of the stars. He fell into the hands of the midwife and (at once) he began to pluck up the grass...." (GeLAE). A Synopsis of the Books of Adam and Eve, $24 \mathrm{E}$.

51 Fletcher-Louis, All the Glory of Adam, 52 .

52 "He was born circumcised; and the Sages declare, At the time when Moses was born, the whole house was filled with light - as it is written here, 'And she saw him that he was good' (Ex 2:2), and elsewhere it is written, 'And God saw the light that it was good' (Gen 1:4)." Sotah 12a.

53 "...she saw that the Shechinah was with him; that is, the 'it' refers to the Shechinah which was with the child." Midrash Rabbah, trans. H. Freedman and M. Simon, 10 vols. (London: Soncino, 1961), 3:29-30.

54 "Moses replied: 'I am the son of Amram, and came out from my mother's womb without prepuce, and had no need to be circumcised; and on the very day on which I was born I found myself able to speak and was able to walk and to converse with my father and mother... when I was three months old I prophesied and declared that I was destined to receive the law from the midst of flames of fire.' "Midrash Rabbah, 7:185.

55 "Rabbi Nathaniel said: the parents of Moses saw the child, for his form was like that of an angel of God. They circumcised him on the eight day and they called his name Jekuthiel." Pirke de Rabbi Eliezer, trans. G. Friedlander, 2nd ed. (New York: Hermon Press, 1965), 378.

56 "She saw the light of the Shechinah playing around him: for when he was born this light filled the whole house, the word 'good' here having the same reference as in the verse 'and God saw the light that it was good' (Gen 1:4)." The Zohar, trans. H. Sperling and M. Simon, 5 vols. (London: Soncino, 1933), 3:35. See also Samaritan Molad Mosheh: "She became pregnant with Moses and was great with child, and the light was present." Samaritan Documents Relating to Their History, Religion and Life, trans. J. Bowman (Pittsburgh: Pickwick, 1977), 287 . 
sacerdotal dimension of the original story. Buried in the ashes of the destroyed sanctuary, the alternative portrayal of the Noachic priestly tradition was neither offensive nor challenging for the heirs of the Pharisaic tradition.

Fletcher-Louis observes that, although Moses, like Noah, is able to speak from his birth and the house of his birth becomes flooded with light, "the differences of the specifically priestly form of that older tradition can be clearly seen." 57 He points out that while Moses is able to speak as soon as he is born, he does not bless God, as do Noah and Melchizedek. ${ }^{58}$ The same paradigm shift is detected in the light symbolism. While in the rabbinic stories the whole house becomes flooded with light, the Mosaic birth texts do not specifically say that Moses is himself the source of light. ${ }^{59}$ These differences indicate that, unlike in 2 Enoch, where the priestly concerns of the editors come to the fore, in the rabbinic accounts they have completely evaporated. Fletcher-Louis notices that "the fact that in the Mosaic stories the child is circumcised at birth indicates his role as an idealized representative of every Israelite: where Noah bears the marks of the priesthood, Moses carries the principal identity marker of every member of Israel, irrespective of any distinction between laity and priesthood." 60

The marked absence of sacerdotal concerns in the later imitations of the story may explain why, although the rabbinic authors knew of the priestly affiliations of the hero of the flood, the story of his priestly birth never appeared in the debates about the priestly successions. This fact demonstrates that the Noachic priestly traditions reflected in 2 Enoch can be placed inside the chronological boundaries of the second temple period, which allows us to safely assume a date of the Melchizedek story and the entire apocalypse before 70 C.E.

57 Fletcher-Louis, All the Glory of Adam, 52.

58 Fletcher-Louis, All the Glory of Adam, 52.

59 Fletcher-Louis reminds that "the illumination of the house through Noah's eyes and the comparison of the light to that of the sun are specifically priestly features of Noah's birth." Fletcher-Louis, All the Glory of Adam, 52-53.

60 Fletcher-Louis, All the Glory of Adam, 53. 